\title{
Peningkatan Hasil Belajar IPS Dengan Menerapkan Pembelajaran Kooperatif Model Snowball Throwing Siswa Kelas IV SDN 19 Parepare
}

\author{
Fajar $^{1}$, Hasnah $^{2}$ \\ 1,2Program Studi PGSD Fakultas Ilmu Pendidikan Universitas Negeri Makassar \\ ${ }^{1}$ fajar@unm.ac.id \\ ²hasnah@unm.ac.id
}

\begin{abstract}
The purpose of this study is to investigate the process of implementation of cooperative learning snowball throwing towards learning the material IPS economic activity in the fourth grade students of SDN 19 Parepare and to find out the results of social studies material increase in economic activity in the fourth grade students of SDN 19 Parepare after the implementation of cooperative learning model of snowball throwing. The type of research that is used is action research with a descriptive design. The focus of this research focused on the process of focusing on the process of implementation of social studies learning materials as well as the focus of economic activity that is the result of improving student learning outcomes social studies material economic activity. Subjects were teacher and fourth grade students of SDN 19 Pare-Pare, a total of 30 people, consisting of 13 men and 17 women. Instrument used was a test, observation and documentation. The student learning outcomes in the first cycle of less qualified because there is still an unmet indicator is the number of students who are able to work with a given test is still a little right, but on the second cycle result rising and qualify good. The results showed that an increase in student learning outcomes in social studies class IV material economic activity SDN 19 Parepare by implementing cooperative learning models snowball throwing.
\end{abstract}

Keywords: social studies learning, cooperative learning model, snowball throwing

\section{PENDAHULUAN}

Pendidikan di Sekolah Dasar

dilaksanakan sesuai dengan prosedur yang memiliki tujuan mengarah kepada tujuan pendidikan nasional yang mengacu pada kurikulum. Tentu dalam peningkatan kualitas pendidikan yang melalui pendidikan formal yakni melalui lembaga sekolahan, yang perlu dilakukan adalah peningkatan metode mengajar di dalam kelas sebab mengajar adalah hal yang menjadi pondasi utama dalam proses pembentukan manusia berpendidikan yang seutuhnya.

Banyak upaya yang telah dilakukan, banyak pula keberhasilan yang telah dicapai meskipun disadari bahwa apa yang telah dicapai belum sepenuhnya memberikan prestasi yang menggembirakan sehingga menuntut renungan, pemikiran dan kerja keras untuk memecahkan masalah-masalah yang dihadapi dalam bidang pendidikan khususnya ditingkat sekolah dasar (SD).
Ilmu Pengetahuan Sosial (IPS) merupakan mata pelajaran pada jenjang pendidikan di tingkat sekolah,yang dikembangkan secara terintegrasi dengan mengambil konsep - konsep esensial dari Ilmuilmu Sosial dan Humaniora. Menurut Sumantri dalam Atika (2010 IPS merupakan suatu program pendidikan dan bukan sub- disiplin ilmu tersendiri. Tujuan pembelajaran Ilmu Pengetahuan Sosial (IPS) terutama membantu para peserta didik selaku warga negara agar mampu menjadi warga negara yang baik, dan mampu untuk mengambil keputusan secara rasional dengan dasar informasi yang mencukupi, dalam kaitan dengan permasalahan sosial yang hasilnya tidak hanya bermanfaat bagi diri pribadi, keluarga, tetapi juga berguna bagi masyarakat dan bangsanya sebagai bentuk perwujudan cinta tanah air.

Berdasarkan hal yang telah dikemukakan maka diharapkan guru dituntun untuk menguasai materi bahan ajar dari konsep-konsep IPS yang ada. Salah satu yang 
termasuk adalah aspek kegiatan perekonomian. Selain itu guru juga harus mampu mengembangkannya dengan pola dan metode mengajar yang tepat agar siswa mampu memahami konsep yang ada serta dapat menarik perhatian siswa untuk lebih berpartisipasi aktif dalam kegiatan pembelajaran. Tercapainya tujuan pembelajaran yang dilaksanakan dapat dilihat dari perubahan tingkah laku siswa setelah memperoleh pengajaran terhadap suatu materi dan pada hasil belajar siswa itu sendiri melalui nilai yang diperoleh terhadap materi yang telah diajarkan pada akhir proses pembelajaran di dalam kelas pada suatu indikator tertentu. Menurut Woordworth (dalam Ismihyani 2000), hasil belajar merupakan perubahan tingkah laku sebagai akibat dari proses belajar. Di samping itu menurut Sudjana (2004, hasil belajar adalah kemampuan-kemampuan yang dimiliki siswa setelah menerima pengalaman belajarnya. Untuk memastikan tujuan pendidikan tercapai dengan benar maka upaya yang perlu ddilakukan adalah memantau kinerja guru di sekolah. Sebagai langkah awal sebelum meneliti maka peneliti melakukan observasi di sekolah.

Peneliti mendapati bahwa hasil belajar siswa masih jauh dari apa yang diharapkan. Hal ini dapat dilihat melalui nilai rata-rata dari 30 siswa kelas IV pada mata pelajaran Ilmu Pengetahuan Sosial adalah 60,83 dengan nilai kriteria ketuntasan minimal yang telah ditetapkan adalah 70 untuk pelajaran IPS. Dari 30 jumlah siswa yang menjadi subjek penelitian terlihat siswa yang mendapatkan nilai 85-100 dengan kategori sangat baik sebanyak 0 siswa atau $0 \%$, siswa yang mendapatkan nilai 70-84 dengan kategori baik sebanyak 4 siswa atau $13,33 \%$, siswa yang mendapatkan nilai 55-69 dengan kategori cukup sebanyak 22 siswa atau 73,33\%, siswa yang mendapatkan nilai 46-54 dengan kategori kurang sebanyak 4 siswa atau $13,33 \%$ dan siswa yang mendapatkan nilai 0-45 dengan kategori sangat kurang sebanyak 0 siswa atau $0 \%$. Hal ini tentu tidak sesuai dengan apa yang diharapkan.
Berdasar hasil yang diperoleh dapat dilihat bahwa nilai dari lebih setengah jumlah siswa tidak memenuhi nilai kriteria ketuntasan minimal sebagaimana yang telah ditetapkan, terdapat 26 siswa yang memperoleh nilai dibawah nilai minimal yang harus dicapai.

Hal ini tentu sangat bertolak belakang dengan pencapaian tujuan pembelajaran yang ingin dicapai. Melihat situasi ini, maka sangat perlu diadakan tindak lanjut yang serius agar hal ini tidak berlanjut ke depannya. Setelah mengobservasi lebih lanjut, ditemukan beberapa hal yang menjadi faktor penyebab dari rendahnya hasil belajar siswa kelas IV di SDN 19 Parepare. Faktor rendahnya hasil belajar siswa ternyata berasal dari guru dan siswa itu sendiri. Adapun penyebab yang berasal dari guru yaitu strategi belajar yang digunakan oleh guru kurang sesuai dengan materi yang diajarkan. Di samping itu, guru kurang melibatkan siswa untuk berpartisipasi secara aktif dalam proses pembelajaran. Sedangkan penyebab yang berasal dari siswa yaitu rendahnya minat belajar siswa pada mata pelajaran IPS. Peneliti berinisiatif mencoba menggunakan model pembelajaran Snowball Trhowing pada pembelajaran IPS untuk lebih mengaktifkan siswa khususnya pada materi kegiatan ekonomi di Indonesia. Model pembelajaran ini dapat digunakan untuk memberikan konsep pemahaman materi yang sulit kepada siswa dan pelaksanaanya cukup mudah untuk diterapkan dalam kegiatan pembelajaran. Snowball Throwing membantu siswa untuk siap menjawab pertanyaan yang diajukan oleh temannya. Selain itu siswa mampu membuat pertanyaan yang bersumber pada materi pembelajaran untuk diajukan kepada temannya. Suasana pembelajaran dengan model kooperatif tipe Snowball Throwing dianggap menyenangkan dan tidak membosankan bagi siswa. Tiap anggota kelompok akan mempersiapkan diri karena pada gilirannya harus menjawab pertanyaan dari temannya yang terdapat dalam bola kertas. Anjar (2013) menjelaskan bahwa snowball throwing yaitu metod epembelajaran yang didalam terdapat unsur-unsur pembelajaran kooperatif sebagai upaya dalam rangka 
mengarahkan perhatian siswa terhadap materi yang disampaikan oleh guru.

Snowball artinya bola salju sedangkan throwing artinya melempar. Snowball Throwing dapat diartikan sebagai model pembelajaran yang menggunakan bola pertanyaan dari kertas yang digulung bulat berbentuk bola kemudian dilemparkan secara bergiliran di antara sesama anggota kelompok. Maulina (2011) menyatakan bahwa model pembelajaran Snowball throwing adalah salah satu model pembelajaran yang dikembangkan berdasarkan pembelajarankontekstual (CTL). Model ini juga digunakan untuk mengetahui sejauh mana pemahaman siswa terhadap penguasaan materi. Pada model pembelajaran ini siswa dibentuk menjadi beberapa kelompok. Dipilih ketua kelompok yang akan mewakili untuk menerima tugas dari guru. Masingmasing siswa membuat pertanyaan yang dibentuk seperti bola (kertas pertanyaan) lalu dilempar ke siswa lain kemudian siswa menjawab pertanyaan dari bola yang didapatkan. Tidak hanya pikiran tetapi model ini juga melatih keterampilan siswa. Berdasarkan hal ini calon peneliti bermaksud untuk mengatasi masalah yang dihadapi dalam proses pembelajaran dengan melakukan penelitian tindakan kelas yang berjudul "Penerapan Model Kooperatif Tipe Snowball Throwing dalam Pembelajaran IPS untuk Meningkatkan Hasil Belajar Siswa Kelas IV SDN 19 Parepare".

\section{METODE PENELITIAN}

Jenis penelitian yang digunakan adalah penelitian tindakan kelas (PTK) yang bertujuan untuk melakukan perbaikan-perbaikan terhadap sistem, cara kerja, proses, isi, dan kompetensi atau situasi pembelajaran. Penelitian tindakan kelas (PTK) ini dilaksanakan di SD Negeri 19 Parepare yang beralamat di Jl. Abu Bakar Lambogo No. 7, kelas penelitiannya yaitu kelas IV dengan jumlah murid 30 orang (13 siswa laki-laki dan 17 siswa perempuan).

Penelitian ini direncanakan dilaksanakan dalam dua siklus, dimana dalam satu siklus terdiri dari dua kali pertemuan. Adapun rangkaian kegiatannya dimulai dari kegiatan pratindakan yang merupakan tahap awal sebelum perencanaa. Setelah itu tahap perencanaan merupakan rancangan tindakan untuk mengatasi masalah tersebut, yang dilanjutkan dengan upaya pelaksanaan tindakan. Tahap selanjutnya adalah observasi. Data yang dikumpulkan kemudian di analisis. Berdasarkan hasil analisis tersebut dilakukanlah refleksi untuk mengetahui hasil dari pelaksanaan tindakan pada siklus pertama.

\section{HASIL \& PEMBAHASAN}

Hasil penelitian yang terdiri atas aktivitas siswa dan guru dalam pembelajaran IPS dengan menerapkan model pembelajaran snowball throwing mengalami peningkatan yang signifikan. Hal ini terbukti dari hasil observasi dalam pembelajaran dan hasil tes siswa yang dilkukan pada akhir pembelajaran. Peningkatan hasil belajar siswa mata pelajaran IPS materi kegiatan ekonomi terlaksana karena adanya kerja sama antara peneliti dan guru kelas yang secara kolaboratif menyusun Rencana Pelaksanaan Pembelajaran yang dilakukan secara berulang-ulang. Di setiap pelaksanaan siklus tedapat adanya kekurangankekurangan yang terjadi didalamnya, namun hal tersebut segera diperbaiki demi peningkatan hasil pembelajaran yang diinginkan.

Pada siklus I pertemuan I, proses pembelajaran yang dilakukan oleh guru dikualisifikasikan Kurang (K). Pelaksanaan pembelajarannya diawali dengan persiapan alat dan bahan yang digunakan peneliti dalam pembelajaran. Di dalam pelaksanaan pembelajaran masih terdapat berbagai kekurang-kekuangan yang dilakukan oleh guru. Namun hal tersebut segera diperbaiki oleh guru untuk peningkatan hasil belajar yang diinginkan. Berikut ini adalah beberapa kekurangan guru didalam pelaksanaan pembelajaran yang ditemukan melalui observasi: 1) pada kegiatan awal, dalam hal ini guru masih kurang dalam mengelolah kelas dengan baik, selain itu apersepsi yang dilakukan masih kurang relevan dengan materi yang akan disajikan 2) penggunaan waktu yang masih kurang efektif dalam melaksanakan tahap-tahap model pembelajaran 3) peneliti belum maksimal melibatkan siswa secara langsung. 4) peneliti belum maksimal dalam membimbing siswa belajar secara kelompok dan dalam menyampaikan 
penjelasan dari guru kepada ketua kelompok untuk teman kelompoknya. Kekurangankekurangan dalam proses pembelajaran pada siklus I pertemuan I ini berdampak pada hasil belajar siswa. Berikut ini hasil evaluasi yang pelaksanaan pembelajaran siklus I pertemuan I. Dari hasil tes yang diberikan menunjukan bahwa dari 30 siswa yang menjadi subyek penelitian pada siklus I pertemuan I terlihat bahwa siswa yang mendapatkan nilai 85-100 dengan kategori sangat baik sebanyak 0 siswa siswa yang mendapatkan nilai 70-84 dengan kategori baik sebanyak 9 siswa atau 30\%, siswa yang mendapatkan nilai 55-69 dengan kategori cukup sebanyak 20 siswa atau $66,67 \%$, dan siswa yang mendapatkan nilai 46-54 dengan kategori kurang sebanyak 1 siswa atau $3,33 \%$, dan siswa yang mendapat nilai $0-45$ dengan kategori sangat kurang sebanyak 0 siswa.

Selanjutnya pada siklus I pertemuan II dengan hasil tes yang diberikan menunjukan bahwa dari 30 siswa yang menjadi subyek penelitian pada siklus I pertemuan II terlihat bahwa siswa yang mendapatkan nilai 85-100 dengan kategori sangat baik sebanyak 0 siswa atau $0 \%$ siswa yang mendapatkan nilai $70-84$ dengan kategori baik sebanyak 12 siswa atau $40 \%$, siswa yang mendapatkan nilai 55-69 dengan kategori cukup sebanyak 14 siswa atau $46,67 \%$, dan siswa yang mendapatkan nilai 46 54 dengan kategori kurang sebanyak 4 siswa atau $13,33 \%$, dan siswa yang mendapat nilai 0 45 dengan kategori sangat kurang sebanyak 0 siswa. Keberhasilan siklus kedua mencapai kualifikasi Baik (B) karena pada kegiatan pembelajaran yang terakhir siswa mampu melaksanakan semua indikator-indikator yang direncanakan oleh peneliti. Hal ini menunjukkan bahwa siswa telah memahami betul langkah-langkah pembelajaran dengan model snowball throwing. Keberhasilan tindakan dari siklus pertama pertemuan I dan II ke siklus kedua pertemuan I dan II karena siswa telah memahami indikator pembelajaran dengan model snowball throwing.

Hasil tes 30 siswa yang menjadi subyek penelitian pada siklus II pertemuan I terlihat bahwa siswa yang mendapatkan nilai 85-100 dengan kategori sangat baik sebanyak 3 siswa atau $10 \%$ siswa yang mendapatkan nilai $70-84$ dengan kategori baik sebanyak 15 siswa atau $50 \%$, siswa yang mendapatkan nilai 55-69 dengan kategori cukup sebanyak 12 siswa atau $40 \%$, dan siswa yang mendapatkan nilai 46-54 dengan kategori kurang sebanyak 0 siswa atau $0 \%$, dan siswa yang mendapat nilai $0-45$ dengan kategori sangat kurang sebanyak 0 siswa.

Berdasarkan hasil tes yang diberikan menunjukan bahwa dari 30 siswa yang menjadi subyek penelitian pada siklus II pertemuan II terlihat bahwa siswa yang mendapatkan nilai 85-100 dengan kategori sangat baik sebanyak 10 siswa atau 33,33\% siswa yang mendapatkan nilai 70-84 dengan kategori baik sebanyak 18 siswa atau $60 \%$, siswa yang mendapatkan nilai 55-69 dengan kategori cukup sebanyak 2 siswa atau 6,67\%, dan siswa yang mendapatkan nilai 46-54 dengan kategori kurang sebanyak 0 siswa atau $0 \%$, dan siswa yang mendapat nilai $0-45$ dengan kategori sangat kurang sebanyak 0 siswa. Dari hasil evaluasi tersebut, kita dapat mengambil kesimpulan bahwa pelaksanaan tindakan pada siklus II ini mengalami peningkatan. Hal ini dikarenakan adanya perbaikan-perbaikan kesalahan yang dilakukan pada siklus I pertemuan I dan II hingga ke siklus II pertemuan I dan II. Dengan melihat indikator keberhasilan yang ditetapkan maka penelitian ini telah berhasil, olehnya pada penelitian di siklus II ini dihentikan karena menggangap hasil pencapaian telah berhasil. Dengan begitu hipotesis yang dibangun oleh peneliti yakni Jika model pembelajaran snowball throwing diterapkan dalam pembelajaran IPS materi kegiatan ekonomi maka hasil belajar siswa kelas IV SDN 19 Parepare meningkat, sudah tercapai sesuai dengan yang diinginkan.

\section{KESIMPULAN \& SARAN}

Dengan menerapkan model kooperatif tipe snowball throwing dalam pembelajaran IPS dapat meningkatkan proses aktivitas belajar siswa kelas IV SDN 19 Parepare. Selain itu dengan penerapan model kooperatif tipe snowball throwing dalam pembelajaran 
IPS dapat meningkatkan hasil belajar siswa kelas IV SDN 19 Parepare.

\section{DAFTAR PUSTAKA}

Anitah, Sri W. 2007. Strategi Pembelajaran di $S D$. Jakarta: Universitas Terbuka.

Anjar. 2013. Metode Pembelajaran Snowball Throwing, om@gin, (online). (diakses 07 April 2013)

Atika. 2010. Konsep Ilmu Pengetahuan Sosial Menurut Para Ahli. (Online). http://atikatikaaziz.blogspot.com/2010/08/ konsep-ilmu-pengetahuan-sosialmenurut.html. (diakses 05 Oktober 2013)

Ginanjar, Anjar. 2013. Metode Pembelajaran Snowball Throwing, om @gin, (online). (diakses 07 April 2013)

Maulina, Deasy. 2011. Model Pembelajaran Snowball Throwing. (Online) http://belajar-sabar-

ikhlas.blogspot.com/2012/10/modelpembelajaran-snowball-throwing.html (diakses 10 Oktober 2013)

Narbuko, Cholid. dan Achmadi, Abu. 2003. Metodologi Penelitian. Jakarta: Bumi Aksara

Sudjana, Nana. 2005. Penilaian Hasil Proses Belajar Mengajar, Bandung: PT Remaja Rosdikarya 